TITLE:

\title{
Influences of temperature and salinity on asexual budding by hydromedusa Proboscidactyla ornata (Cnidaria: Hydrozoa: Proboscidactylidae)
}

\section{$\operatorname{AUTHOR}(\mathrm{S}):$}

Kawamura, Mariko; Kubota, Shin

\section{CITATION:}

Kawamura, Mariko .... [et al]. Influences of temperature and salinity on asexual budding by hydromedusa

Proboscidactyla ornata (Cnidaria: Hydrozoa: Proboscidactylidae). Journal of the Marine Biological Association of the United Kingdom 2008, 88(8): 1601-1606

ISSUE DATE:

2008-12-18

URL:

http://hdl.handle.net/2433/187916

\section{RIGHT:}

(c) Marine Biological Association of the United Kingdom 2008 


\title{
Influences of temperature and salinity on asexual budding by hydromedusa Proboscidactyla ornata (Cnidaria: Hydrozoa: Proboscidactylidae)
}

\author{
MARIKO KAWAMURA AND SHIN KUBOTA \\ Seto Marine Biological Laboratory, Field Science Education and Research Center, Kyoto University, 459 Shirahama, Nishimuro, \\ Wakayama, 649-2211 Japan
}

\begin{abstract}
At the head of Tanabe Bay, on the Pacific coast of Japan, dense populations of Proboscidactyla ornata medusae were observed at $24^{\circ} \mathrm{C}, 34$ psu from July 2001 to September 2002 (maximum 472.4 individuals $\mathrm{m}^{-3}$ ). In the laboratory, 288 immature medusae of P. ornata collected from Tanabe Bay in May-June 2006 were cultured individually and fed with asphyxiated Artemia nauplii under 12 experimental conditions (four different temperatures $\left(17^{\circ} \mathrm{C}, 20^{\circ} \mathrm{C}, 23^{\circ} \mathrm{C}\right.$ and $\left.26^{\circ} \mathrm{C}\right)$ combined with three different salinities (28 psu, $31 \mathrm{psu}$ and $34 \mathrm{psu})$ ). For 30 days, $94 \%$ of the medusae survived at all conditions. The maximum number of clones produced was 0.32 clones medusa ${ }^{-1}$ day ${ }^{-1}$ at $20^{\circ} \mathrm{C}, 34$ psu; the number of medusae increased 10.5 times in 30 days. The maturation percentage at $23^{\circ} \mathrm{C}(54.2-58.3 \%)$ was higher than at $17^{\circ} \mathrm{C}(12.5-25.0 \%)$ and was positively correlated with the number of nauplii ingested. Temperature-specificity of energy usage was observed: $20^{\circ} \mathrm{C}$ for asexual budding and $23^{\circ} \mathrm{C}$ for sexual reproduction. The direct relationship between budding and temperature is demonstrated among hydromedusae for the first time in this study. Additionally, the influence of salinity on budding suggests a hypothesis on an advantage of budding at offshore and high saline waters.
\end{abstract}

Keywords: asexual reproduction, medusan population, mass occurrence, environmental factor

Submitted 1 December 2007; accepted 19 August 2008

\section{INTRロDUCTIDN}

Hydromedusae can play an important role as predators of mesozooplanktonic crustaceans when they occur in abundance at coastal waters (Arai, 2001; Matsakis \& Conover, 1991; Purcell \& Arai, 2001; Colin et al., 2005). In some small species $(<10 \mathrm{~mm}$ in bell height), dense population is known to decrease copepods rapidly (Greve, 1994).

Among 842 species of hydromedusae except for siphonophores (Bouillon \& Boero, 2000), the medusae of 50 species are known to produce clonal medusae by asexual budding (Bouillon, 1994). Some budding hydromedusae are widely distributed in the world, which is believed to be an advantage of the dispersal by budding (Bouillon, 1994; Kitamura et al., 2003).

The budding hydromedusae sometimes form dense populations (Werner, 1958; Costello \& Mathieu, 1995) and dominate the mesozooplanktonic medusa community (Carré \& Carré, 1990; Hansson et al., 2005). In Hydractinia minima (Trinci, 1903), Rathkea octopunctata (M. Sars, 1835), and Lizzia blondina Forbes, 1848, the abundance has been reported to achieve several hundreds per metre cubed in coastal waters (Toyokawa \& Terazaki, 1994; Ballard \& Myers, 2000; Chaplygina \& Dautova, 2005). Such abundance has not been frequently reported among hydromedusae

Corresponding author:

M. Kawamura

Email: kawamuram@fish-u.ac.jp unless holopelagic siphonophores or trachymedusae are occasionally accumulated at coastal waters (Greve, 1994; Ueno \& Mitsutani, 1994). Budding by the medusa can be important for the population explosion of the medusae.

Rapid budding is induced at an appropriate water temperature. In laboratory studies, 50 medusae of $R$. octopunctata increased 6.3 times (19 survivors of the primary medusa + 288 clones) at $6-11^{\circ} \mathrm{C}$ (rising during the culture) after 31 days in culture (Werner, 1958), and 100 medusae of Eucheilota paradoxica Mayer, 1900 increased 6.8 times (62 survivors of the primary medusa +618 clones) at $24^{\circ} \mathrm{C}$ after 22 days in culture (Carré \& Carré, 1990). These two studies explain the sudden appearance of dense populations of these medusae and suggest that budding by the medusa contributes to a growing medusa population in the field in relation to the water temperature: one of the important environmental factors that accelerate budding.

Additionally, maturation and food availability influence budding. The maturation can suppress budding because asexual reproduction and sexual reproduction are suggested not to occur simultaneously in one individual as mentioned for various hydromedusae (Bouillon, 1994). In R. octopunctata medusae, full maturation occurs after ceasing asexual budding at $9-12^{\circ} \mathrm{C}$, which is higher than the suitable temperature for budding (Werner, 1958). Food availability clearly affects asexual reproduction such as budding in various hydroids (Arai, 1992), which has not been considered in laboratory studies of budding hydromedusa. 
A budding medusa Proboscidactyla ornata (McCrady, 1859) (Anthomedusae: Proboscidactylae) is distributed circumglobally in warm coastal waters (Kramp, 1961). This abundant medusa has been reported in Papua New Guinea and in the eel pond at Woods Hole, MA in the United States (Hargitt, 1904; Bouillon, 1994). In China, large numbers of medusae of $P$. ornata damage the pond aquaculture of crab and shrimp on the Zhejiang coast every year (Shao \& Chang, 2004). Although it is unknown what factor induces the formation of the dense population of $P$. ornata, Brinckmann \& Vannucci (1965), who revealed the life cycle of $P$. ornata with its hydroid on sabellid polychaetes, mentioned that the medusa frequently occurs at $20^{\circ} \mathrm{C}, 33-37$ psu in the field. The influences of both temperature and salinity on budding need to be examined in laboratory experiments to clarify the relationship between budding and abundance in the field.

In Tanabe Bay on the Pacific coast, dense populations of $P$. ornata medusae appeared at the head of the bay during regular sampling between July 2001 and September 2002. In this study, we examined the influence of temperature and salinity on asexual budding of $P$. ornata medusae in the laboratory taking into consideration maturation and food availability and discussed the effect of budding on the formation of the dense population in the field.

\section{MATERIALS AND METHDDS}

\section{Field sampling}

Medusae of Proboscidactyla ornata were collected in the morning (9:00-11:00) every two weeks from 3 July 2001 to 2 September 2002 at the head of Tanabe Bay $\left(33.68^{\circ} \mathrm{N}\right.$ $135.36^{\circ} \mathrm{E}$ ) using T/RV 'Janthina III', Seto Marine Biological Laboratory, Kyoto University. Two replicated vertical tows, from $2 \mathrm{~m}$ above the bottom to the surface, were made using a plankton net $(0.56 \mathrm{~m}$ mouth diameter, $1.9 \mathrm{~m}$ length and $0.33 \mathrm{~mm}$ mesh size), at a haul speed of $1 \mathrm{~m}$ per second. The two replicates were averaged. The filtered water volume was calculated using a flow meter. Large medusae and ctenophores $(>10 \mathrm{~mm}$ in size) were removed from the sample to prevent preying on $P$. ornata. Live medusae were kept cool with ice during transportation to the laboratory, and sorted under a stereomicroscope within 24 hours of collecting. Water temperature and salinity were recorded vertically at one-second intervals using a set of data loggers (MDS-CT and MDS-TD, Alec Electronics Cooperation) while collecting medusae. Salinity units ( $\mathrm{psu} \approx$ parts per thousand) were unified throughout this study. The vertical profile was averaged.

\section{Laboratory culture}

Immature medusae of $P$. ornata, bell height $1-2 \mathrm{~mm}$ and with 4 tentacles, were collected with a pipette from the surface water at the head of Tanabe Bay at temperatures of $21^{\circ} \mathrm{C}$ to $24^{\circ} \mathrm{C}$ in May-June 2006 and were cultured under 12 conditions $\left(17^{\circ} \mathrm{C}, 20^{\circ} \mathrm{C}, 23^{\circ} \mathrm{C}, 26^{\circ} \mathrm{C} \times 28 \mathrm{psu}, 31 \mathrm{psu}, 34 \mathrm{psu}\right)$ in artificial seawater (Marine Art BR, Senju Pharmaceutical Co., Ltd). Water temperature and salinity were controlled with four incubators and a refractometer (Atago Co., Ltd), respectively. In each of the 12 experimental conditions,
24 medusae were kept individually on a 24 -well microplate filled with $3 \mathrm{ml}$ seawater per well. In total, 288 medusae were examined for 30 days.

Small young medusae of $P$. ornata are difficult to maintain with Artemia nauplii (Calder, 1970). Since P. ornata medusae of bell height 1-2 mm sometimes did not catch enough swimming nauplii to survive, they became thin and small and did not feed on frozen or dead nauplii in our preliminary experiment. In this case, asphyxiated Artemia nauplii ( 5 hours after hatching out and ceasing aeration) were useful, because the recovery time of 20 minutes was sufficient for the medusae to catch them. After rinsing the accumulating asphyxiated nauplii on the bottom of a jar with fresh medium, we daily provided the medusa with one drop of nauplii from a Pasteur pipette (100-200 individuals per medusa). One hour after feeding, we moved the medusa into another microplate filled with fresh medium.

\section{Data analysis}

The clonal medusae, asexually produced by the primary medusae, were picked up from the well of the microplate when we changed the seawater daily and counted them. The number of Artemia nauplii ingested was also recorded daily by counting the number of nauplius-eyes in the stomach of the medusa. As the stomach of the medusa is small enough, the nauplius-eyes of all Artemia ingested could be observed clearly.

After completing a culture, we measured the percentage of maturation and sex-ratios under each experimental condition. In the rare case of a medusa with both medusa buds and developed ovary or testis, we dealt with it as a mature individual because such a medusa can spawn. As indicators of body development, we measured the number of marginal tentacles and the bell height.

To detect energy consumption due to stress in a certain environment where the medusa shows low activity in asexual and sexual reproduction, we measured the respiration of medusae individually every hour after feeding using a dissolved oxygen meter ( $781 \mathrm{~b}$, Strathkelvin Instruments Ltd.) and a Coolnics circulator (CTE-82A, Yamato Scientific Co., Ltd.). During the experiment, we provided oxygen for the medusa every two hours via a pipette so as not to expose the medusa to low oxygen.

The non-parametric Kruskal-Wallis test was used to test for statistically significant differences among the 12 groups of cultured medusae under each different condition. Where appropriate, directed pairwise comparisons of individual groups were conducted using Dunn's test. As the medusae at $20^{\circ} \mathrm{C}$ (average $1.9 \mathrm{~mm}$ in bell height) were significantly larger than those at $17^{\circ} \mathrm{C}, 23^{\circ} \mathrm{C}$ and $26^{\circ} \mathrm{C}$ (average $1.4^{-1.5} \mathrm{~mm}$ ) (Dunn's test, $P<$ $0.05)$, we compared the averages between size-selected medusae and the rest to eliminate the possibility that measured values such as the number of clones depends on body size. The numbers of pooled medusae of $1.7-1.9 \mathrm{~mm}$ bell height-i.e. the larger medusae among the cultured ones whose productivity may be higher than smaller ones due to ingesting more preywere $16,45,14$ and 15 at $17^{\circ} \mathrm{C}, 20^{\circ} \mathrm{C}, 23^{\circ} \mathrm{C}$ and $26^{\circ} \mathrm{C}$, respectively. No significant difference was detected in bell height of these size-selected medusae between the different temperatures (Kruskal-Wallis test, $P>0.05$ ). The Mann-Whitney's $U$-test was used to test for statistically significant differences between size-selected medusae and the rest in the value measured. 


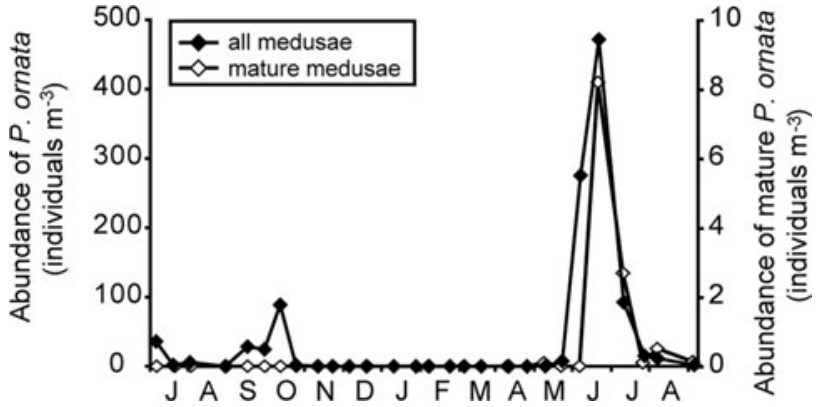

Fig. 1. The seasonal change of abundance of Proboscidactyla ornata medusae (mature medusae are shown as open square) between 18 June 2001 and 2 September 2002 at the head of Tanabe Bay.

If there was no difference between them, we treated the value that did not depend on the body size in the range we examined. Statistical analyses were performed with commercially available packages using SigmaStat Version 3.0.1 (SPSS, Inc.).

\section{RESULTS}

At the head of Tanabe Bay, the abundance of Proboscidactyla ornata medusae peaked on 9 October 2001 (89.4 individuals $\mathrm{m}^{-3}$ ) and on 19 June 2002 (472.4 individuals $\mathrm{m}^{-3}$ ) (black squares in Figure 1). The abundance of mature medusae peaked on 19 June 2002 ( 8.2 individuals $\mathrm{m}^{-3}$ ) (open squares in Figure 1). Water temperature ranged from $13.0^{\circ} \mathrm{C}$ (7 January 2002) to $27.9^{\circ} \mathrm{C}$ (17 July 2001) (black line in Figure 2). Salinity ranged from 31.9 psu (13 September 2001) to 34.7 psu (4 March, 7 May and 4 June in 2002) (grey line in Figure 2). The medusae occurred above $18.0^{\circ} \mathrm{C}$ and at all the salinities observed. At peak of abundance of the medusae on 19 June 2002, water temperature and salinity were $24.6^{\circ} \mathrm{C}$ and 34.2 psu respectively.

After 30 days in culture, 21-24 medusae of $P$. ornata survived per 24 medusae in each condition (Table 1), which was equal to $94 \%$ of the survival percentage on an average in all of the 12 experimental conditions. No significant difference was found among the different temperatures and salinities (Kruskal-Wallis test, $P>0.05$ ).

The number of clones at $20^{\circ} \mathrm{C}\left(0.22-0.32\right.$ clones medusa $^{-1}$ day $^{-1}$ ) was higher than at $17^{\circ} \mathrm{C}, 23^{\circ} \mathrm{C}$, and $26^{\circ} \mathrm{C}$ (0.03-0.11 clones medusa ${ }^{-1}$ day $^{-1}$ ) except for between $20^{\circ} \mathrm{C}, 28 \mathrm{psu}$

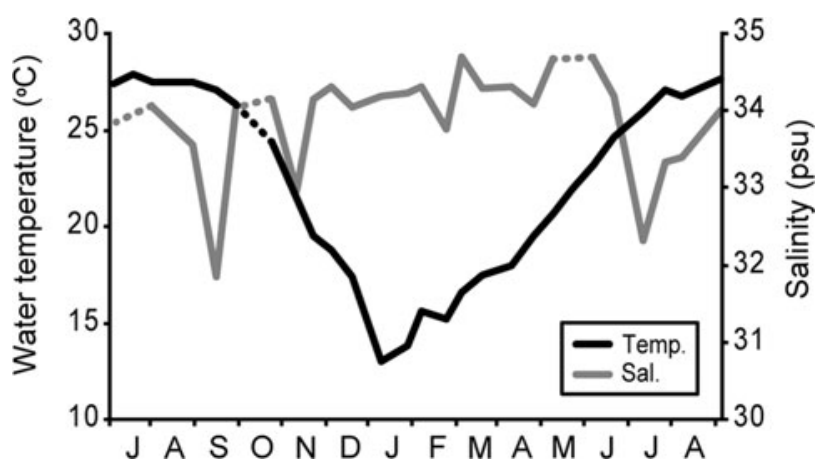

Fig. 2. The seasonal change of water temperature (black line) and salinity (grey line) between 18 June 2001 and 2 September 2002 at the head of Tanabe Bay. Each dotted line includes a missing value.
Table 1. The numbers of survivors and clonal medusae produced, and the growth of Proboscidactyla ornata under each experimental condition after 30 days in culture.

\begin{tabular}{lllll}
\hline $\begin{array}{l}\text { Experimental } \\
\text { conditions }\end{array}$ & $\begin{array}{l}\text { No. of } \\
\text { survivors } \\
\text { per 24 } \\
\text { primary } \\
\text { medusae }\end{array}$ & $\begin{array}{l}\text { No. of clonal } \\
\text { medusae } \\
\text { produced in }\end{array}$ & $\begin{array}{l}\text { Percentage } \\
\text { of medusa } \\
\text { with more } \\
\text { than } 4\end{array}$ & $\begin{array}{l}\text { Growth } \\
\text { size-selected } \\
\text { medusae (\%) }\end{array}$ \\
& 22 & 81 & $\begin{array}{l}\text { tentacles } \\
\end{array}$ & \\
\hline $17^{\circ} \mathrm{C}, 28 \mathrm{psu}$ & 22 & 4.2 & 1.1 \\
$17^{\circ} \mathrm{C}, 31 \mathrm{psu}$ & 22 & 35 & 0.0 & 15.4 \\
$17^{\circ} \mathrm{C}, 34 \mathrm{psu}$ & 23 & 46 & 4.2 & 4.2 \\
$20^{\circ} \mathrm{C}, 28 \mathrm{psu}$ & 21 & 160 & 0.0 & 20.4 \\
$20^{\circ} \mathrm{C}, 31 \mathrm{psu}$ & 23 & 199 & 8.3 & 21.5 \\
$20^{\circ} \mathrm{C}, 34 \mathrm{psu}$ & 21 & 230 & 0.0 & 20.4 \\
$23^{\circ} \mathrm{C}, 28 \mathrm{psu}$ & 22 & 69 & 8.3 & 29.5 \\
$23^{\circ} \mathrm{C}, 31 \mathrm{psu}$ & 24 & 42 & 0.0 & 11.6 \\
$23^{\circ} \mathrm{C}, 34 \mathrm{psu}$ & 24 & 80 & 12.5 & 0.0 \\
$26^{\circ} \mathrm{C}, 28 \mathrm{psu}$ & 23 & 59 & 16.7 & 17.9 \\
$26^{\circ} \mathrm{C}, 31 \mathrm{psu}$ & 24 & 51 & 16.7 & 17.6 \\
$26^{\circ} \mathrm{C}, 34 \mathrm{psu}$ & 22 & 23 & 4.2 & 17.6 \\
\hline
\end{tabular}

*(bell height after 30 days/bell height immediately before starting the experiment) -1 .

and $23^{\circ} \mathrm{C}, 28 \mathrm{psu} ; 23^{\circ} \mathrm{C}, 34 \mathrm{psu}$; and $17^{\circ} \mathrm{C}, 28 \mathrm{psu}$ (Dunn's test, $P<0.05$ ) (Figure 3). At $20^{\circ} \mathrm{C}$, the number of clones at $34 \mathrm{psu}$ ( 0.32 clones medusa ${ }^{-1}$ day $^{-1}$ ) was higher than at $28 \mathrm{psu}$ (0.22 clones medusa ${ }^{-1} \mathrm{day}^{-1}$ ) (Dunn's test, $P<0.05)$. At $17^{\circ} \mathrm{C}, 23^{\circ} \mathrm{C}$ and $26^{\circ} \mathrm{C}$, no difference was found between different salinities (Kruskal-Wallis test, $P>0.05$ ). After 30 days in culture, the number of medusae at $20^{\circ} \mathrm{C}$ increased by 7.5 to 10.5 times, in contrast to an increase of 1.9 to 4.3 times at $17^{\circ} \mathrm{C}, 23^{\circ} \mathrm{C}$ and $26^{\circ} \mathrm{C}$ (Table 1). The number of clones at $17^{\circ} \mathrm{C}, 20^{\circ} \mathrm{C}, 23^{\circ} \mathrm{C}$ and $26^{\circ} \mathrm{C}$ showed no difference between size-selected medusae (black squares in Figure 3 ) and the rest (Mann - Whitney's $U$-test, $P>0.05$ ).

After 30 days in culture, at $23^{\circ} \mathrm{C}$, the maturation percentages (54.2-58.3\%) were higher than at $17^{\circ} \mathrm{C}(12.5-25.0 \%)$ (Figure 4) (Dunn's test, $P<0.05)$. No difference between different salinities was detected (Kruskal-Wallis test, $P>0.05$ ). At $20^{\circ} \mathrm{C}$, however, the maturation percentage $(16.7 \%)$ at 34 psu was much lower than at $28 \mathrm{psu}$ and $31 \mathrm{psu}(41.7-45.8 \%)$. In sizeselected medusae, the maturation percentage was also highest at $23^{\circ} \mathrm{C}$ and lowest at $17^{\circ} \mathrm{C}$. The sex-ratio averaged 3:4 (male:

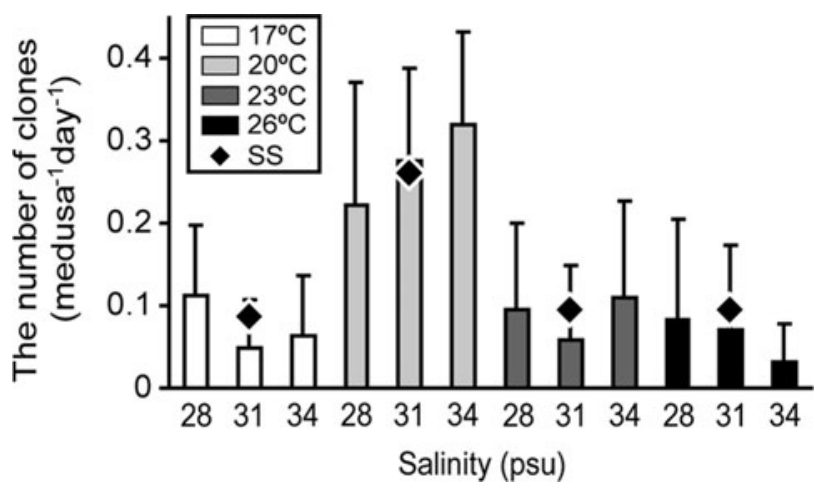

Fig. 3. The number of clones produced medusa ${ }^{-1}$ day $^{-1}$ by Proboscidactyla ornata in culture ( 12 conditions of different salinities and temperatures). SS, mean of size-selected medusae $(1.7-1.9 \mathrm{~mm}$ in bell height) at each temperature. 


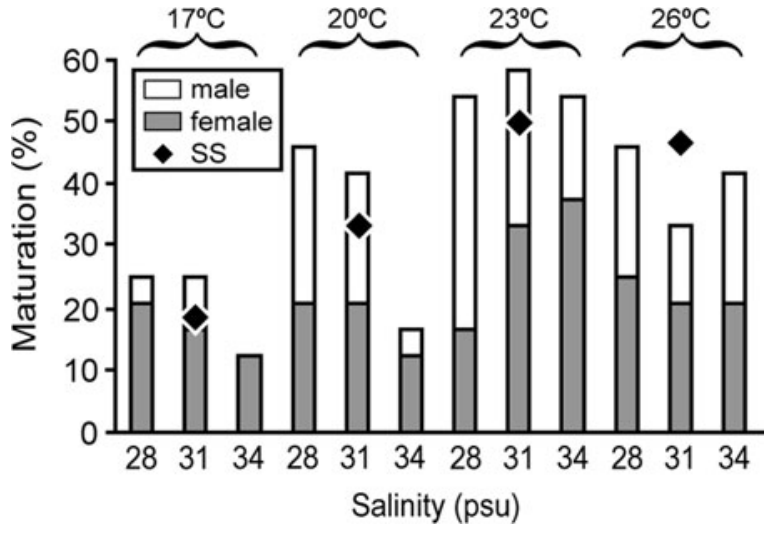

Fig. 4. The percentage maturation of Proboscidactyla ornata after 30 days in culture (12 conditions of different salinities and temperatures). SS, maturation percentage of size-selected medusae (1.7-1.9 $\mathrm{mm}$ in bell height) at each temperature.

female) and showed no change in different conditions (Kruskal-Wallis test, $P>0.05$ ).

The number of nauplii ingested at $17^{\circ} \mathrm{C}$ ranged from 1.9 to 2.0 nauplii medusa ${ }^{-1}$ day $^{-1}$, which was lower than at $20^{\circ} \mathrm{C}$, $23^{\circ} \mathrm{C}$ and $26^{\circ} \mathrm{C}\left(2.7-3.1\right.$ nauplii medusa ${ }^{-1}$ day $^{-1}$ ) (Dunn's test, $P<0.05$ ) (Figure 5). No difference was found among different salinities (Kruskal-Wallis test, $P>0.05$ ). The average number of nauplii ingested at $17^{\circ} \mathrm{C}, 20^{\circ} \mathrm{C}, 23^{\circ} \mathrm{C}$ and $26^{\circ} \mathrm{C}$ was no different in size-selected medusae (black squares in Figure 5) from the rest (Mann-Whitney's $U$-test, $P<0.05)$. The number of nauplii ingested was positively correlated with maturation percentage $\left(r^{2}=0.49, P>0.05\right)$.

The percentage of medusae with more than four tentacles tended to increase after 30 days in culture when the water temperature was high (Table 1). However, there was no significant difference between different experimental temperatures (Kruskal-Wallis test, $P>0.05$ ). The percentage growth of sizeselected medusae ( $=$ bell height after 30 days per initial one (bell height immediately before starting the experiment) - 1) ranged from $0.0 \%$ to $29.5 \%$ but showed no difference in the different conditions (Kruskal-Wallis test, $P>0.05$ ) (Table 1 ).

The oxygen consumption every hour for 10 hours after feeding ranged from a fifth to the same as that immediately after feeding. The accumulated oxygen consumption during

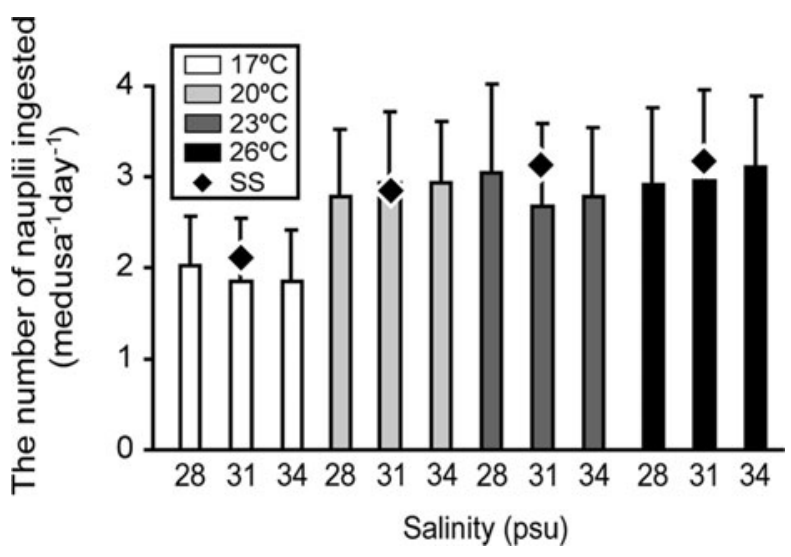

Fig. 5. The number of Artemia nauplii ingested medusa ${ }^{-1}$ day $^{-1}$ by Proboscidactyla ornata in culture ( 12 conditions of different salinities and temperatures). SS, mean of size-selected medusae $(1.7-1.9 \mathrm{~mm}$ in bell height) at each temperature.

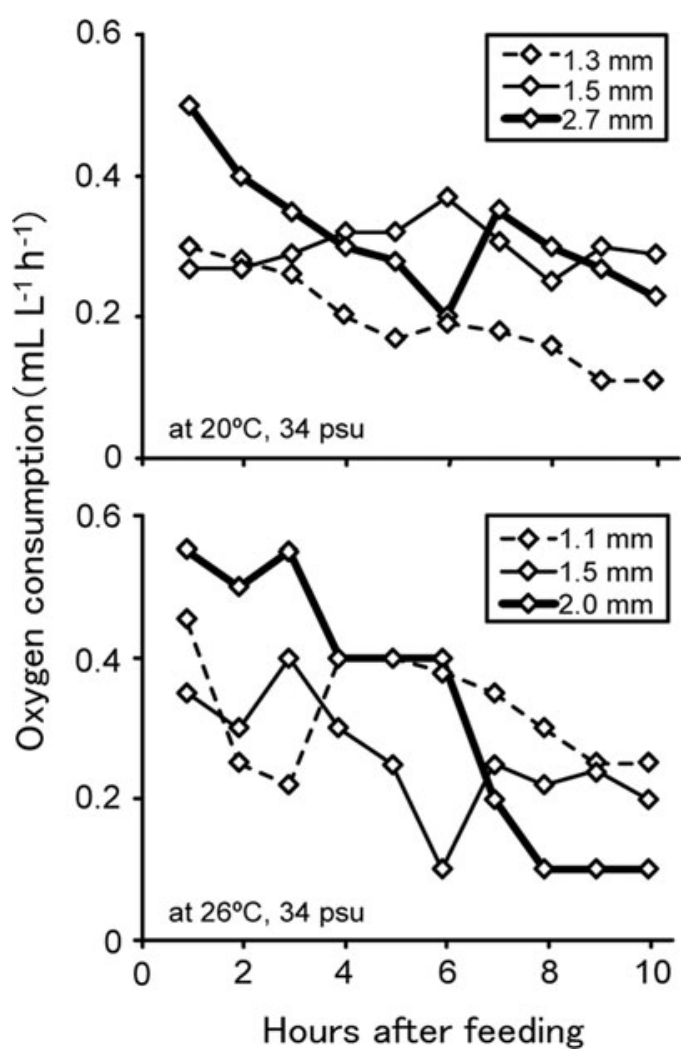

Fig. 6. The oxygen consumption of Proboscidactyla ornata of three different sizes (dotted, thin and bold lines in order of size) every hour immediately after feeding at $20^{\circ} \mathrm{C}, 34 \mathrm{psu}$ (top) and at $26^{\circ} \mathrm{C}, 34 \mathrm{psu}$ (bottom).

10 hours showed no significant difference between $20^{\circ} \mathrm{C}$ and $26^{\circ} \mathrm{C}$ (Mann-Whitney’s U-test, $P>0.05$ ) (Figure 6).

\section{DISCUSSION}

A dense population of Proboscidactyla ornata medusae occurs at $24^{\circ} \mathrm{C}$ in Tanabe Bay (Figures $1 \& 2$ ). We also observed 98.0 individuals $\mathrm{m}^{-3}$ at $24.1^{\circ} \mathrm{C}$ on 18 June 2001 off the station we regularly examined in this study. In the laboratory, medusae produced maximally 0.32 clones medusa ${ }^{-1}$ day $^{-1}$ at $20^{\circ} \mathrm{C}$, 34 psu (Figure 3). This temperature did not coincide with the dense population in Tanabe Bay. However, our laboratory data can explain the frequent occurrence of the medusa at $20^{\circ} \mathrm{C}$ in Brazil (Brinckmann \& Vannucci, 1965). In Tanabe Bay, the first occurrence of the P. ornata medusa in 2002 was in May (Figure 1), at a water temperature of $20^{\circ} \mathrm{C}$ and a salinity of 34 psu (Figure 2), a month when rainfall was lower and temperature had risen. The most suitable conditions can cause a dense population after one month. In contrast, the abundance of medusae on 9 October 2001 was less than a fifth of that on 19 June 2002 and occurred during the decrease of water temperature. At this season, water temperature decreases rapidly to less than $20^{\circ} \mathrm{C}$ in November. In the laboratory, at $17^{\circ} \mathrm{C}$, the medusa produced clones as at $23^{\circ}$ and $26^{\circ} \mathrm{C}$, however, the maturation percentage was the lowest among them (Figure 4). Additionally, a low temperature can be disadvantageous to asexual reproduction and growth of the medusae in the long term due to the small number of nauplii ingested (Figure 5). Therefore, the 
Tanabe Bay population in October was low because they were exposed to unsuitable conditions before growth as in June. Occurrence of a dense population of $P$. ornata can be accounted for by suitable water temperature for budding at the medusa stage.

At $20^{\circ} \mathrm{C}$, the number of clones at 34 psu was 1.5 times as many as at 28 psu (Figure 3 ) in contrast to the maturation percentage at $34 \mathrm{psu}$ which was a half of that at 28-31 psu (Figure 4). In Tanabe Bay, peak abundance of the medusa occurred at high salinity (34.2 psu) as in Brazilian waters (Brinckmann \& Vannucci, 1965). This influence of salinity on budding of the medusa is also considerable despite higher influence by temperature on population growth, which is explained by a hypothesis on an ecological advantage of budding as follows. The neritic medusa will gain an advantage of dispersal by budding in high salinity offshore waters. On the other hand, there is an advantage of sexual reproduction in low saline waters inside the bay because planula larvae easily find suitable substrates to attach. At temperatures suitable for medusae, it is advantageous to increase the population by asexual budding offshore rather than to mature and spawn.

Actually, in Tanabe Bay, mature medusae of $P$. ornata achieved only 8.2 individuals $\mathrm{m}^{-3}$ at $24.6^{\circ} \mathrm{C}$ (Figure 1 ). It has been reported that mature medusae of this species and of Eucheilota paradoxica occur rarely in the field (Uchida \& Sugiura, 1975; Carré \& Carré, 1990). Most P. ornata medusae do not mature in the field despite experiencing a water temperature of $23^{\circ} \mathrm{C}$, which accelerates maturation as demonstrated in this study (Figure 4). Therefore, only a small part of the population is able to participate in sexual reproduction in Tanabe Bay. The amount of food ingested also can limit maturation in terms of the cost of sexual reproduction. We found a positive correlation between the number of nauplii ingested and the percentage maturation (Figures $4 \& 5$ ). A female medusa produces 20 eggs every two days in the laboratory at greater energy cost than asexual budding. Rarity of mature medusae in Tanabe Bay can be explained if the population of medusae quickly depletes food organisms during an asexual population boom before maturation. However, the medusa has the potential to mature successfully if food availability is higher than Tanabe Bay.

The average percentage of medusae with more than four tentacles was highest $(12.5 \%)$ at $26^{\circ} \mathrm{C}$, while the growth percentage of size-selected medusae showed no significant difference among different conditions (Table 1). Increase in the number of tentacles as temperature increased was not statistically significant, and we found the same oxygen consumption at $26^{\circ} \mathrm{C}$ as at $20^{\circ} \mathrm{C}$ (Figure 6). It is suggested that the medusa at $26^{\circ} \mathrm{C}$ used energy for body growth rather than consume additional energy in response to stress. A possible difference of energy usage at different temperatures is suggested: for asexual reproduction at $20^{\circ} \mathrm{C}$, for sexual reproduction at $23^{\circ} \mathrm{C}$, and for body development at $26^{\circ} \mathrm{C}$. Growth above the minimum body size for asexual and sexual reproduction means long term accumulation of energy reserves in the body. Such medusae can survive the summer season of low food availability due to seasonal stratification in Tanabe Bay (Koike et al., 1993).

In the laboratory, the percentage survival of $P$. ornata was high and showed no difference among different conditions (Table 1). The direct relationship between budding and water temperature is demonstrated for the first time in this
Table 2. Comparison of suitable conditions for asexual budding among three budding hydromedusae.

\begin{tabular}{|c|c|c|c|}
\hline Species & $\begin{array}{l}\text { Proboscidactyla } \\
\text { ornata }\end{array}$ & $\begin{array}{l}\text { Rathkea } \\
\text { octopunctata }\end{array}$ & $\begin{array}{l}\text { Eucheilota } \\
\text { paradoxica }\end{array}$ \\
\hline $\begin{array}{l}\text { Number of survivors } \\
\text { /number of } \\
\text { primary medusae }\end{array}$ & $21 / 24$ & $19 / 50$ & $62 / 100$ \\
\hline $\begin{array}{l}\text { Maximum } \\
\text { number of clonal } \\
\text { medusae } \\
\text { produced/days } \\
\text { cultured }\end{array}$ & $230 / 30$ & $288 / 31$ & $618 / 22$ \\
\hline $\begin{array}{l}\text { Conditions when } \\
\text { maximum } \\
\text { number of clones } \\
\text { observed }\end{array}$ & $20^{\circ} \mathrm{C}, 34 \mathrm{psu}$ & $6-11^{\circ} \mathrm{C}$ & $24^{\circ} \mathrm{C}$ \\
\hline $\begin{array}{r}\text { Experimental } \\
\text { conditions }\end{array}$ & $\begin{array}{r}17^{\circ} \mathrm{C}, 20^{\circ} \mathrm{C}, 23^{\circ} \mathrm{C} \\
26^{\circ} \mathrm{C} \times 28 \mathrm{psu} \\
31 \mathrm{psu}, 34 \mathrm{psu}\end{array}$ & $\begin{array}{c}6-11^{\circ} \mathrm{C} \\
11-13^{\circ} \mathrm{C} \\
16^{\circ} \mathrm{C}\end{array}$ & $\begin{array}{l}9^{\circ} \mathrm{C}, 13^{\circ} \mathrm{C}, \\
15^{\circ} \mathrm{C}, 18^{\circ} \mathrm{C}, \\
21^{\circ} \mathrm{C}, 24^{\circ} \mathrm{C}\end{array}$ \\
\hline References & This study & Werner (1958) & $\begin{array}{c}\text { Carré \& Carré } \\
\text { (1990) }\end{array}$ \\
\hline
\end{tabular}

study because the number of clones depends not only on temperature but also on the number of survivors in Eucheilota paradoxica and Rathkea octopunctata (Werner, 1958; Carré \& Carré, 1990).

The temperature which accelerates budding is different among the three species of hydromedusa (Table 2). Rathkea octopunctata experienced a maximum increase of 6.3 times at $6-11^{\circ} \mathrm{C}$ in 31 days (Werner, 1958), and Eucheilota paradoxica increased 6.8 times at $24^{\circ} \mathrm{C}$ in 22 days (Carré \& Carré, 1990) (Table 2). Suitable water temperatures could differentiate the peaks of the medusa populations in the field and decrease competition among geographically co-occurring budding hydromedusae.

Asexual reproduction by budding at the medusa stage plays an important role in the life history of the budding hydromedusa $P$. ornata, which can result in the growth of population. If a dense population of $P$. ornata depletes its food organisms in Tanabe Bay, it has a considerable potential as a predator of mesozooplankton in which polychaete larvae and copepods are preferred (Kitamura, 2003). For future study, the feeding impact of $P$. ornata needs to be ascertained in order to estimate its ecological significance as a predator in the field.

\section{ACKNDWLEDGEMENTS}

We are grateful to Professor S. Ueno (National Fisheries University) for his loan of a plankton net. We thank the captain Mr Y. Yamamoto and the crew Mr K. Okita of T/RV 'Janthina III' (Seto Marine Biological Laboratory, Kyoto University) for their kind help throughout samplings in Tanabe Bay. Thanks are also due to Professor Y. Shirayama (Seto Marine Biological Laboratory, Kyoto University) for his loan of data loggers, oxygen meter and Coolnics circulator, and Dr E. Robson (School of Biological Sciences, University of Reading) for her careful reading of our manuscript, and two referees of the JMBA for their valuable comments. This work was supported by a grant from the Mikimoto Fund for Marine Ecology. 


\section{REFERENCES}

Arai M.N. (1992) Active and passive factors affecting aggregations of hydromedusae: a review. Scientia Marina 56, 99-108.

Arai M.N. (2001) Pelagic coelenterates and eutrophication: a review. Hydrobiologia 451, 69-87.

Ballard L. and Myers A. (2000) Observations on the seasonal occurrence and abundance of gelatinous zooplankton in Lough Hyne, Co. Cork, south-west Ireland. Biology and Environment: Proceedings of the Royal Irish Academy 100B, 75-83.

Bouillon J. (1994) Classe des Hydrozoaires. In P.-P. Grassé and J. Doumenc (eds) Traité de zoologie, volume 3 (2). Paris: Masson, pp. 29-416.

Bouillon J. and Boero F. (2000) Synopsis of the families and genera of the hydromedusae of the world, with a list of the worldwide species. Thalassia Salentina 24, 47-296.

Brinckmann A. and Vannucci M. (1965) On the life-cycle of Proboscidactyla ornata (Hydromedusae, Proboscidactylidae). Pubblicazioni della Stazione Zoologica di Napoli 34, 357-365.

Calder D.R. (1970) North American record of the hydroid Proboscidactyla ornata (Hydrozoa, Proboscidactylidae). Chesapeake Science 11, 130-132.

Carré D. and Carré C. (1990) Complex reproductive cycle in Eucheilota paradoxica (Hydrozoa: Leptomedusae): medusae, polyps and frustules produced from medusa stage. Marine Biology (Berlin) 104, 303-310.

Chaplygina S.F. and Dautova T.N. (2005) Finding of the hydromedusa Hydractinia minima (Trinci, 1903) (Cnidaria: Hydrozoa: Hydractiniidae) in Peter the Great Bay, Sea of Japan. Russian Journal of Marine Biology 31, 141-145.

Colin S.P., Costello J.H., Graham W.M. and Higgins J. (2005) Omnivory by the small cosmopolitan hydromedusa Aglaura hemistoma. Limnology and Oceanography 50, 1264-1268.

Costello J.H. and Mathieu H.W. (1995) Seasonal abundance of medusae in Eel Pond, Massachusetts, USA during 1990-1991. Journal of Plankton Research 17, 199-204.

Greve W. (1994) The 1989 German Bight invasion of Muggiaea atlantica. ICES Journal of Marine Science 51, 355-358.

Hansson L.J., Moeslund O., Kiørboe T. and Riisgård H.U. (2005) Clearance rates of jellyfish and their potential predation impact on zooplankton and fish larvae in a neritic ecosystem (Limfjorden, Denmark). Marine Ecology Progress Series 304, 117-131.

Hargitt C.W. (1904) The medusae of the Woods Hole region. Bulletin of the Bureau of Fisheries 24, 21-79.
Kitamura M. (2003) Feeding ecology of jellyfishes. Bulletin of the Plankton Society of Japan 50, 103-109. [In Japanese with English abstract.]

Kitamura M., Tanaka Y. and Ishimaru T. (2003) Coarse scale distributions and community structure of hydromedusae related to water mass structures in two locations of Japanese waters in early summer. Plankton Biology and Ecology 50, 43-54.

Koike Y., Nakaguchi Y., Hiraki K., Takeuchi T., Kokubo T. and Ishimaru T. (1993) Species and concentrations of selenium and nutrients in Tanabe Bay during red tide due to Gymnodinium nagasakiense. Journal of Oceanography 49, 641-656.

Kramp P.L. (1961) Synopsis of the medusae of the world. Journal of the Marine Biological Association of the United Kingdom 40, 7-469.

Matsakis S. and Conover R.J. (1991) Abundance and feeding of medusae and their potential impact as predators on other zooplankton in Bedford Basin (Nova Scotia, Canada) during spring. Canadian Journal of Fisheries and Aquatic Science 48, 1419-1430.

Purcell J.E and Arai M.N. (2001) Interactions of pelagic cnidarians and ctenophores with fish: a review. Hydrobiologia 451, 27-44.

Shao G. and Chang K. (2004) The removal of jellyfish in maricultural pond. Journal of the Shanghai Fisheries University 13, 75-77. [In Chinese and English abstract.]

Toyokawa M. and Terazaki M. (1994) Seasonal variation of medusae and ctenophores in the innermost part of Tokyo Bay. Bulletin of the Plankton Society of Japan 41, 71-75.

Uchida T. and Sugiura Y. (1975) On the formation of medusa buds in Proboscidactyla ornata. Publications of the Seto Marine Biological Laboratory 22, 347-354.

Ueno S. and Mitsutani A. (1994) Small-scale swarm of a hydrozoan medusa Liriope tetraphylla in Hiroshima Bay, southern Japan. Bulletin of the Plankton Society of Japan 41, 165-166.

and

Werner B. (1958) Die Verbreitung und das Jahreszeitliche Auftreten der Anthomeduse Rathkea octopunctata M. Sars sowie die Temperaturabhängigkeit ihrer Entwicktung und Fortpflanzung. Helgoländer Wissenschaftliche Meeresuntersuchungen 6, 137-170.

\section{Correspondence should be addressed to:}

M. Kawamura

Seto Marine Biological Laboratory, Field Science Education and Research Center,

Kyoto University, 459 Shirahama, Nishimuro, Wakayama, 649-2211 Japan email: kawamuram@fish-u.ac.jp 